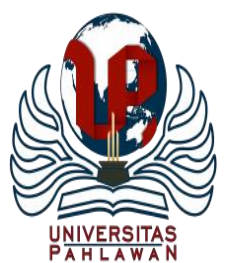

Edukatif : Jurnal Ilmu Pendidikan Volume 3 Nomor 5 Tahun 2021 Halm 2539 - 2550

EDUKATIF: JURNAL ILMU PENDIDIKAN

Research \& Learning in Education

https://edukatif.org/index.php/edukatif/index

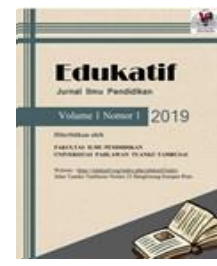

\title{
Pengembangan Media Pembelajaran Audio Visual dengan Pendekatan Contextual Teaching Learning (CTL) untuk Meningkatkan Motivasi Belajar Siswa
}

\author{
Wahyu Fitri Avania ${ }^{1 凶}$, Ni’matush Sholikhah ${ }^{2}$ \\ Universitas Negeri Surabaya, Indonesia ${ }^{1,2}$ \\ E-mail : wahyu.17080554065@mhs.unesa.ac.id ${ }^{1}$, nimatushsholikhah@unesa.ac.id $^{2}$
}

\begin{abstract}
Abstrak
Berdasarkan observasi yang dilakukan peneliti bahwa motivasi belajar X IPS 1 SMA N 14 Surabaya tergolong rendah, sehingga untuk membantu meningkatkan motivasi belajar siswa peneliti mengembangkan media pembelajaran audio visual dengan pendekatan Contextual Teaching Learning (CTL). Tujuan dari penelitian ini yaitu menganalisis kelayakan, kepraktisan serta keefektifan penggunaan media dalam meningkatkan motivasi belajar siswa. Jenis penelitian yang digunakan yaitu Research and Development $(R n D)$ dengan model pengembangan ADDIE yang meliputi : (1) Analysis, (2) Design (3) Development, (4) Implementation, dan (5) Evaluate. Teknik analis data yang digunakan meliputi validasi ahli, kuisioner respon siswa dan kuisioner motivasi belajar yang dianalisis menggunakan analisis gain score. Hasil penelitian ini yaitu media pembelajaran audio visual dengan pendekatan Contextual Teaching Learning (CTL) mendapat skor rata-rata 4,4 dalam kategori sangat layak, prosentase rata-rata kuisioner respon siswa $89,81 \%$ dalam kategori sangat layak, dan nilai gain score sebesar 0,77 dalam kategori tinggi. Sehingga diperoleh kesimpulan bahwa media pembelajaran audio visual dengan pendekatan Contextual Teaching Learning (CTL) memenuhi kriteria kelayakan dan kepraktisan serta efektif meningkatkan motivasi belajar siswa X IPS 1 SMA N 14 Surabaya.
\end{abstract}

Kata Kunci: media audio visual, pendekatan Contextual Teaching Learning (CTL), motivasi belajar.

\section{Abstract}

Based on observations made by researchers that learning motivation for X IPS 1 SMA N 14 Surabaya is low, so to help increase student motivation, researchers developed audio-visual learning media with Contextual Teaching Learning (CTL) approaches. The purpose of this study is to analyze the feasibility, practicality and the effectiveness of the use of media to increasing students' learning motivation. The type of research used is Research and Development (RnD) with the ADDIE development model which includes: (1) Analysis, (2) Design (3) Development, (4) Implementation, and (5) Evaluate. Data analysis techniques used include expert validation, student response questionnaires and learning motivation questionnaires which were analyzed using gain score analysis. The results of this study are the audio-visual learning media with Contextual Teaching Learning (CTL) approach got an average score of 4.4 in the very feasible category, the average percentage of student response questionnaires was $89.81 \%$ in the very feasible category, and the gain score was 0.77 in the high category. So it can be concluded that the audio-visual learning media with Contextual Teaching Learning (CTL) approach meets the eligibility and practicality criteria and is effective in increasing the learning motivation of X IPS 1 students at SMA N 14 Surabaya.

Keywords: audio visual media, Contextual Teaching Learning (CTL) approach, learning motivation.

Copyright (c) 2021 Wahyu Fitri Avania, Ni'matush Sholikhah

$\triangle$ Corresponding author

Email : wahyu.17080554065@mhs.unesa.ac.id

DOI : https://doi.org/10.31004/edukatif.v3i5.885

ISSN 2656-8063 (Media Cetak)

ISSN 2656-8071 (Media Online) 
2540 Pengembangan Media Pembelajaran Audio Visual dengan Pendekatan Contextual Teaching Learning (CTL) untuk Meningkatkan Motivasi Belajar Siswa - Wahyu Fitri Avania, Ni'matush Sholikhah

DOI: https://doi.org/10.31004/edukatif.v3i5.885

\section{PENDAHULUAN}

Dalam dunia pendidikan di suatu negara, Sumber Daya Manusia yang berkualitas memiliki pengaruh yang besar terhadap kemajuan pembangunan negara kearah yang lebih baik dan berkualitas (Warti, 2018). Oleh karena itu pemerintah terus berupaya untuk mewujudkan pendidikan Nasional yang berintegritas. Upaya yang dapat dilakukan pemerintah dalam hal mewujudkan hal tersebut adalah dengan memanfaatkan perkembangan teknologi di bidang pendidikan (Rupawati et al., 2017). Oleh karena itu adanya kerjasama oleh semua pihak akan membantu tercapainya tujuan pembelajaran yang telah ditetapkan. Suatu pendidikan dikatakan berhasil ketika tujuan pembelajaran yang telah ditetapkan dapat dicapai. Tingginya motivasi belajar oleh siswa sangat dibutuhkan dalam hal tercapainya tujuan suatu pembelajaran (Sardiman, 2007). Motivasi belajar adalah pemacu ataupun dorongan yang berasal dari internal maupun eksternal individu untuk dapat mencapai tujuan tertentu (Syupriyanti et al., 2019). Motivasi menjadi hal yang mendasar dalam proses belajar karena menjadi pendorong dan pemacu semangat siswa untuk belajar (Syarwah et al., 2019). Maka dari itu untuk dapat mencapai tujuan yang ditetapkan tidak lepas dari motivasi belajar yang tinggi dari siswa.

Orang yang tekun dan rajin mengerjakan tugas, tidak mudah menyerah saat menghadapi kesulitan dan menunjukkan sikap minat saat melakukan proses pembelajaran adalah ciri-ciri orang yang tinggi motivasi belajarnya (Sardiman, 2007). Namun realita yang terjadi di lapangan tidak sesuai dengan teori yang ada dimana ketika peneliti melakukan kegiatan PLP di SMA Negeri 14 Surabaya. Dimana peneliti menemukan bahwa motivasi belajar siswa X IPS 1 SMA N 14 Surabaya tergolong rendah dari pada dua kelas lainnya yaitu X IPS 2 dan X IPS 3. Ditunjukkan dengan prosentase siswa yang mau mengerjakan tugas ekonomi hanya sebesar $29,17 \%$ dari keseluruhan siswa dan prosentase kehadiran siswa saat pembelajaran ekonomi hanya 53,46\% dari keseluruhan siswa. Dengan berdasarkan hal tersebut bahwa motivasi belajar ekonomi siswa $\mathrm{X}$ IPS 1 SMA N 14 Surabaya tergolong rendah dan menunjukkan ketidaksesuaian atau gap dengan teori mengenai ciri-ciri anak yang memiliki motivasi dalam dirinya. Dengan motivasi belajar yang cukup rendah akan sulit bagi siswa untuk dapat berhasil mencapai tujuan pembelajaran yang ditetapkan. Tinggi rendahnya motivasi belajar oleh siswa disebabkan oleh dua faktor utama yang meliputi faktor instrinsik atau dari dalam dirinya serta faktor ekstrinsik atau faktor dari luar (Ryan \& Deci, 2020). Untuk meningkatkan motivasi siswa dalam belajar tidak hanya dari perkataan maupun perbuatan, tetapi bisa menggunakan media untuk mendukung prose pembelajaran agar lebih menarik perhatian siswa (Syarwah et al., 2019). Menurut Hamalik (2009) menggunakan media pembelajaran interaktif seperti video pembelajaran dapat menjadi salah satu alternative dalam membangkitkan moivasi belajar siswa.

Menurut Fauzyah et al. (2019) media pembelajaran merupakan suatu alat pembangkit motivasi belajar siswa. To make learning effective and efficient is to use media in the learning process (Winarto et al., 2020). Media yang telah terbukti efektif digunakan dalam penyajian materi ekonomi untuk anak SMA adalah media pembelajaran audio visual (Rupawati et al., 2017). Media audio visual adalah jenis media pembelajaran yang dilengkapi dengan dua unsur gambar dan suara yang dinilai lebih baik dari media pembelajaran lain (Bambang et al., 2015). Penggunaan media audio visual dalam proses belajar mengajar terbukti efektif meningkatkan motivasi belajar siswa, seperti pada penelitian oleh Werdhiana et al. (2020) bahwa implemetasi pembelajaran menggunakan perangkat audio visual berhasil motivasi dan minat belajar siswa menjadi lebih meningkat.

Peneliti melakukan survei kepada siswa X IPS 1 SMA N 14 Surabaya berupa kuisioner kesulitan materi yang diisi oleh 27 siswa. Dari kuisioner tersebut diketahui bahwa 66,7\% siswa merasa kesulitan pada materi terbetuknya keseimbangan pasar dan struktur pasar. Dapat diartikan bahwa mayoritas siswa X IPS 1 merasa kesulitan pada materi tersebut. Maka dari itu dibutuhkan pendekatan yang sesuai sehingga materi yang diajarkan mudah diserap oleh siswa. Dikarenakan materi tersebut erat kaitannya deengan kehidupan seharihari dibutuhkan pendekatan yang melibatkan siswa secara langsung dengan kehidupan sehari-harinya. Adapun 
pendekatan yang sesuai adalah pendekatan kontekstual atau Contextual Teaching Learning (CTL) karena pendekatan ini mengaitkan proses belajar dengan kegiatan sehari-hari siswa, dan dalam prosesnya siswa dilibatkan secara langsung dalam proses pembelajaran (Novisya \& Desnita, 2020). Menurut Syupriyanti et al. (2019) langkah-langkah yang digunakan dalam pembelajaran dengan pendekatan Contextual Teaching Learning (CTL) yaitu : konstruktivisme, inquiry/menemukan, bertanya, Learning community, pemodelan/contoh belajar, refleksi serta penilaian yang sebenarnya.

Beberapa penelitian mengemukakan bahwa penggunaan media audio visual dan juga penggunaan pendekatan Contextual Teaching Learning (CTL) dalam proses pembelajaran mampu membuat motivasi siswa dalam belajar menjadi meningkat. Seperti pada penelitian Syarwah et al. (2019) dengan judul Peningkatan Motivasi Belajar Siswa Menggunakan Media Audio Visual pada Pembelajaran Bahasa Indonesia memperoleh hasil bahwa penggunaan media audio visual pada saat pembelajaran Bahasa Indonesia mampu meningkatkan motivasi belajar siswa. Perbedaan penelitian ini dengan penelitian yang dilakukan oleh peneliti adalah penelitian ini hanya menggunakan media audio visual tanpa pendekatan Kontekstual dalam meningkatkan motivasi belajar siswa, sedangkan penelitian yang dilakukan peneliti menggunakan media audio visual dengan pendekatan Contextual Teaching Learning (CTL) dalam meningkatkan motivasi belajar siswa. Penelitian lain membahas pengaplikasian pendekatan Contextual Teaching Learning (CTL) dalam meningkatkan motivasi belajar siswa oleh Ekowati et al. (2015) memperoleh hasil bahwa penggunaan pendekaan kontekstual dalam proses pembelajaran mampu meningkatkan motivasi belajar siswa. Perbedaan penelitian ini dengan penelitian yang dilakukan peneliti adalah penelitian ini meneliti pengaplikasian pendekatan kontekstual untuk menungkatkan motivasi belajar siswa sedangkan penelitian yang dilakukan oleh peneliti menggabungkan media audio visual dengan pendekatan kontekstual untuk meningkatkan motivasi belajar siswa. Kebanyakan penelitian terdahulu hanya membahas pengaruh penggunaan media terhadap motivasi ataupun hasil belajar dan juga penggunaan pendekatan kontekstual dalam meningkatkan motivasi belajar ataupun hasil belajar. Namun penelitian yang dilakukan peneliti menggabungkan keduanya untuk dapat meningkatkan motivasi belajar siswa secara maksimal dimasa pandemic ini.

Oleh karenanya peneliti ingin untuk dapat melakukan penelitian pengembangan suatu media audio visual dengan menggunakan pendekatan Contextual Teaching Learning (CTL) pada materi terbentuknya keseimbangan pasar dan struktur pasar. Peneliti berharap dengan dikembangkannya media ini dapat membantu meningkatkan motivasi siswa pada saat melakukan proses belajar ekonomi. Berdasarkan uraian diatas perlu dilaksanakan penelitian mengenai pengembangan media pembelajaran audio visual dengan pendekatan Contextual Teaching Learning (CTL) pada materi terbentuknya keseimbangan pasar dan struktur pasar dengan tujuan mengetahui kelayakan, kepratisan dan keefektifan media dalam meningkatkan motivasi belajar siswa X IPS 1 SMA Negeri 14 Surabaya.

\section{METODE PENELITIAN}

Jenis penelitian ini adalah jenis penelitian dan pengembangan atau biasa disebut dengan Research and Development $(R n D)$. Dengan model pengembangan yang digunakan adalah ADDIE yang dikembangkan oleh Dick and Carry tahun 1996 dalam (Mulyatiningsih, 2012) yang dalam pelaksanaannya terdapat beberapa tahapan kegiatan yang meliputi Analisis (Analysis), Desain produk (Design), Pengembangan produk (Development), Implementasi produk (Implementation) dan evaluasi (Evaluate).

Prosedur penelitian yang digunakan pada penelitian ini terdiri dari beberapa tahapan meliputi : (1) Tahap analisis (Analysis), dalam tahap yang pertama ini dilakukan pengamatan terhadap masalah yang dihadapi siswa X IPS 1 SMA N 14 Surabaya, analisis materi, analisis tujuan pembelajaran dan analisis mengenai indikator yang digunakan dalam penilaian motivasi belajar siswa; (2) Tahap desain Produk (Design) yang meliputi penyusunan materi, penentuan fitur dalam media, pencarian gambar, penyesuaian gambar 
dengan audio dan juga perekaman audio pengisi; (3) Tahap pengembangan produk (Development), dimana pada kegiatan ini dilaksanakan pengembangan media sesuai desain yang ada; (4) Tahap implementasi produk (Implementation), yang meliputi telaah yang dilakukan oleh para ahli, revisi produk, validasi produk oleh para ahli, uji instrument motivasi belajar dan juga percobaan media di lapangan guna mengetahui respon oleh siswa mengenai penggunaan media; (5) Tahap evaluasi (Evaluation) meliputi tahap penilaian motivasi belajar siswa $\mathrm{X}$ IPS 1 SMA N 14 Surabaya dengan mengisi kuisioner motivasi belajar sebelum dan setelah proses pembelajaran menggunakan media yang dikembangkan.

Teknik yang digunakan dalam pengumpulan data penelitian ini yaitu berupa lembar telaah yang diisi oleh ahli yang nantinya digunakan untuk sebagai dasar perbaikan media pembelajaran, lembar validasi yang diisi oleh ahli sebagai dasar mengukur kelayakan media, lembar respon yang diisi siswa untuk mengetahui kepraktisan media dan kuisioner motivasi belajar yang digunakan untuk mengetahui keefektifan media dalam meningkatkan motivasi belajar siswa. Data yang dihimpun selanjutnya akan dianalisis oleh peneliti secara deskripstif kualitatif maupun kuantitatif, dibawah ini merupakan teknik yang digunakan dalam analis data penelitian pengembangan ini:

\section{Analisis Lembar Telaah dan Validasi}

Lembar telaah yang telah diberikan oleh ahli media dan ahli materi akan dilakukan analisis secara deskriptif kualitatif guna nantinya digunakan sebagai acuan dalam perbaikan media. Hasil validasi berupa angka dengan skala likert yang diadaptasi dari Sugiyono (2016) kemudian dianalisis secara deskriptif kuantitatif guna mengetahui kelayakan media audio visual dengan pendekatan Contextual Teaching Learning $(C T L)$ berdasar pada rumus berikut :

$$
X=\frac{\sum X}{n}
$$

Kemudian diinterpretasikan secara kualitatif berdasarkan rumus konversi skala lima yang disajikam dalam tabel berikut :

Tabel 1 Konfersi skor actual menjadi skala lima

\begin{tabular}{lllll}
\hline Skor & Rumus & Rentang Nilai & Nilai & Kategori/keterangan \\
\hline 5 & $\mathrm{Mi}+1,50 \mathrm{SBi}<\mathrm{X}$ & $\mathrm{X}>4,01$ & $\mathrm{~A}$ & Sangat layak \\
\hline 4 & $\mathrm{Mi}+0,50 \mathrm{SBi}<\mathrm{X} \leq \mathrm{Mi}+1,50 \mathrm{Sbi}$ & $3,34<\mathrm{X} \leq 4,01$ & $\mathrm{~B}$ & Layak \\
\hline 3 & $\mathrm{Mi}-0,50 \mathrm{SBi}<\mathrm{X} \leq \mathrm{Mi}+0,50 \mathrm{Sbi}$ & $2,26<\mathrm{X} \leq 3,34$ & $\mathrm{C}$ & Cukup layak \\
\hline 2 & $\mathrm{Mi}-1,50 \mathrm{SBi}<\mathrm{X} \leq \mathrm{Mi}-0,50 \mathrm{SBi}$ & $1,99<\mathrm{X} \leq 2,26$ & $\mathrm{D}$ & Kurang layak \\
\hline 1 & $\mathrm{X} \leq \mathrm{Mi}-1,50 \mathrm{SBi}$ & $\mathrm{X} \leq 1,99$ & $\mathrm{E}$ & Sangat Kurang layak \\
\hline Sumber: & Azwar $(2007)$ & &
\end{tabular}

Sumber: Azwar (2007)

2. Analisis Kuisioner Respon Siswa

Hasil kuisioner respon siswa berupa angka menggunakan skala likert yang nantinya dianalisis secara deskriptif kuantitatif guna mengetahui kepraktisan penggunaan media audio visual dengan pendekatan Contextual Teaching Learning (CTL) berdasarkan rumus berikut :

$$
\text { Presentase Respon }=\frac{\sum \text { skor keseluruhan }}{\sum \text { skor maksimal }} \times 100 \%
$$

Tabel 2 Kriteria Interpretasi Skor Kuisioner Respon Siswa

\begin{tabular}{ll}
\hline \multicolumn{1}{c}{ Skor } & \multicolumn{1}{c}{ Kriteria } \\
\hline $\mathrm{x} \geq 81 \%$ & Sangat layak \\
\hline $61 \% \leq \mathrm{x}<81 \%$ & Layak \\
\hline $41 \% \leq \mathrm{x}<61 \%$ & Cukup layak \\
\hline $21 \% \leq \mathrm{x}<41 \%$ & Tidak layak \\
\hline $\mathrm{x}<21 \%$ & Sangat tidak layak \\
\hline
\end{tabular}


2543 Pengembangan Media Pembelajaran Audio Visual dengan Pendekatan Contextual Teaching Learning (CTL) untuk Meningkatkan Motivasi Belajar Siswa - Wahyu Fitri Avania, Ni'matush Sholikhah

DOI: https://doi.org/10.31004/edukatif.v3i5.885

Sumber : Riduwan (2012)

3. Analisis Kuisioner Motivasi Belajar Siswa

Kuisioner motivasi belajar dibagikan kepada siswa sebelum dan setelah penggunaan media. Hasil kuisioner berupa angka dengan berdasar skala likert yang nantinya dilakukan analisis secara deskriptif kualitatif dengan menggunakan uji gain score untuk mengetahui perubahan motivasi belajar siswa. Cara perhitungannya menggunakan rumus dibawah ini :

$$
\text { Gain score }=\frac{\text { skor kuisioner akhir }- \text { skor kuisioner awal }}{\text { skor maksimum }- \text { skor kuisioner awal }}
$$

Tabel 3 Kriteria peningkatan motivasi belajar

\begin{tabular}{cc}
\hline Rentang & Kategori \\
\hline $0,7<\mathrm{g} \leq 1$ & Tinggi \\
\hline $0,3 \leq \mathrm{g} \leq 0,7$ & Sedang \\
\hline $0 \leq \mathrm{g}<0,3$ & Rendah \\
\hline Sumber : Hake (1999) &
\end{tabular}

\section{HASIL DAN PEMBAHASAN PENELITIAN}

Penelitian ini berhasil menciptakan sebuah produk yang berupa media pembelajaran audio visual dengan penggunakan pendekatan Contextual Teaching Learning (CTL) pada materi terbentuknya kesimbangan pasar dan struktur pasar. Dengan menggunakan model pengembangan ADDIE oleh Dick and Carry dalam (Mulyatiningsih, 2012) yang meliputi beberapa tahapan dibawah ini :

1. Tahap Analisis (Analysis)

Dalam tahap ini peneliti menganalisis beberapa aspek diantaranya (1) analisis masalah yang dihadapi oleh siswa, ditemukan bahwa motivasi belajar siswa X IPS 1 paling rendah diantara kelas lainnya yang dibuktikan dengan tingkat kehadiran dan jumlah siswa yang mengumpulkan tugas rendah, (2) analis materi, disini dilakukan analisis kesulitan materi oleh siswa X IPS 1 menggunakan google form dan ditemukan bahwa 66,7\% siswa merasa kesulitan pada materi terbentuknya keseimbangan pasar dan struktur pasar, (3) melakukan analisis tujuan pembelajaran yang dimasukkan kedalam media dan yang ke (4) analisis indikator motivasi belajar yang digunakan untuk mengukur perubahan motivasi belajar.

2. Desain Produk (Design)

Dalam tahap ini mencakup beberapa kegiatan diantaranya yaitu (1) menyusun materi terbentuknya keseimbangan pasar dan struktur pasar sesuai dengan langkah-langkah pendekatan kontekstual yang meliputi konstruktivisme, inquiry, bertanya, learning community, pemodelan, refleksi dan penilaian yang sebenarnya, (2) melakukan cek plagiasi materi dimana materi yang telah disusun memperoleh hasil plagiasi sebesar 12\%, (3) menentukan fitur dalam media yang meliputi sampul, Kompetensi Dasar dan tujuan, materi sesuai pendekatan kontekstual dan contoh soal dengan pembahasan, (4) melakukan pengambilan gambar dan pencarian gambar yang free lisensi di situs web pixabay.com, (5) penentuan materi yang hanya ditampilkan dan materi yang diiiringi dengan audio, dan yang terakhir (6) melakukan perekaman audio.

3. Pengembangan Produk

Dalam tahap ini dilakukan pembuatan media audio visual berdasarkan desain yang telah dibuat, dibawah ini merupakan fitur dalam media yang dikembangkan : 

(CTL) untuk Meningkatkan Motivasi Belajar Siswa - Wahyu Fitri Avania, Ni'matush Sholikhah DOI: https://doi.org/10.31004/edukatif.v3i5.885

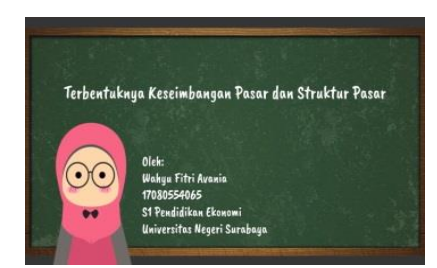

sampul awal

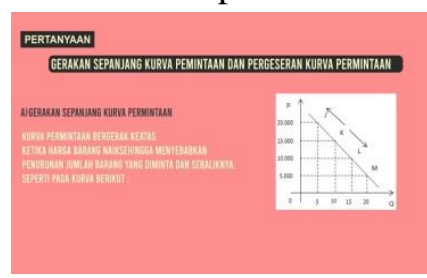

Gambar 3. Materi dengan pendekatan kontekstual

$\begin{array}{ll}\text { Gam } & \text { Gambar } 2 . \\ \text { bar } & \text { Dasar dan } \\ 1 . & \\ \text { Desa } & \\ \text { in } & \end{array}$

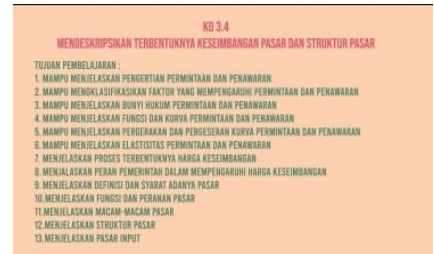

Kompetensi

Tujuan

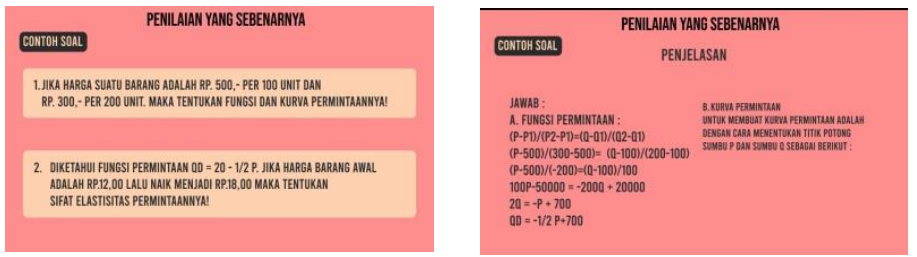

Gambar 4. Contoh soal dan pembahasan

\section{Implementasi Produk (Implementation)}

Dalam tahapan kegiatan ini dilakukan percobaan media di lapangan. Media pembelajaran dapat digunakan dalam proses pembelajaran setelah melewati tahapan yaitu (1) tahap telaah dilakukan oleh Ibu Ni'matush Sholikhah selaku dosen Program Studi S1 Pendidikan Ekonomi sebagai ahli materi maupun ahli media, (2) tahap revisi produk merupakan tahap perbaikan berdasarkan hasil telaah oleh ahli (3) tahap validasi media untuk mengetahui kelayakan media (4) menguji instrument motivasi belajar menggunakan spss 16 yang meliputi uji validitas dan reliabilitas yang mulanya terdiri dari 12 pertanyaan menjadi 9 pertanyaan valid dengan pertanyaan tidak valid berjumlah 3 butir, (5) uji coba media di lapangan dan mengambil data respon siswa untuk mengukur kepraktisan penggunaan media.

5. Tahap evaluasi (evaluation)

Dalam tahap ini dilakukan penilaian motivasi belajar menggunakan kuisioner yang diisi oleh siswa sebelum dan setelah penggunaan media. data hasil kuisioner nantinya akan dianalisis menggunakan analisis gain score guna mengetahui peningkatan motivasi belajar.

Dibawah ini merupakan pembahasan sesuai tujuan penelitian ini berdasarkan tahap penelitian yang disampaikan diatas :

\section{Kelayakan Media Audio Visual dengan Pendekatan Contextual Teaching Learning (CTL)}

Guna mengetahui kelayakan media pembelajaran audio visual dengan pendekatan Contextual Teaching Learning (CTL) dapat ditinjau dari lembar telaah dan validasi yang diisi oleh para ahli. Lembar telaah digunakan sebagai bahan untuk revisi/perbaikan produk. Dibawah ini merupakan perbandindingan produk sebelum dan sesudah revisi berdasarkan hasil telaah oleh para ahli :

Tabel 4. Perbandingan media sebelum dan setelah dilakukan revisi

\begin{tabular}{lll}
\hline No & Sebelum perbaikan & Setelah perbaikan \\
\hline
\end{tabular}


2545 Pengembangan Media Pembelajaran Audio Visual dengan Pendekatan Contextual Teaching Learning (CTL) untuk Meningkatkan Motivasi Belajar Siswa - Wahyu Fitri Avania, Ni'matush Sholikhah DOI: https://doi.org/10.31004/edukatif.v3i5.885

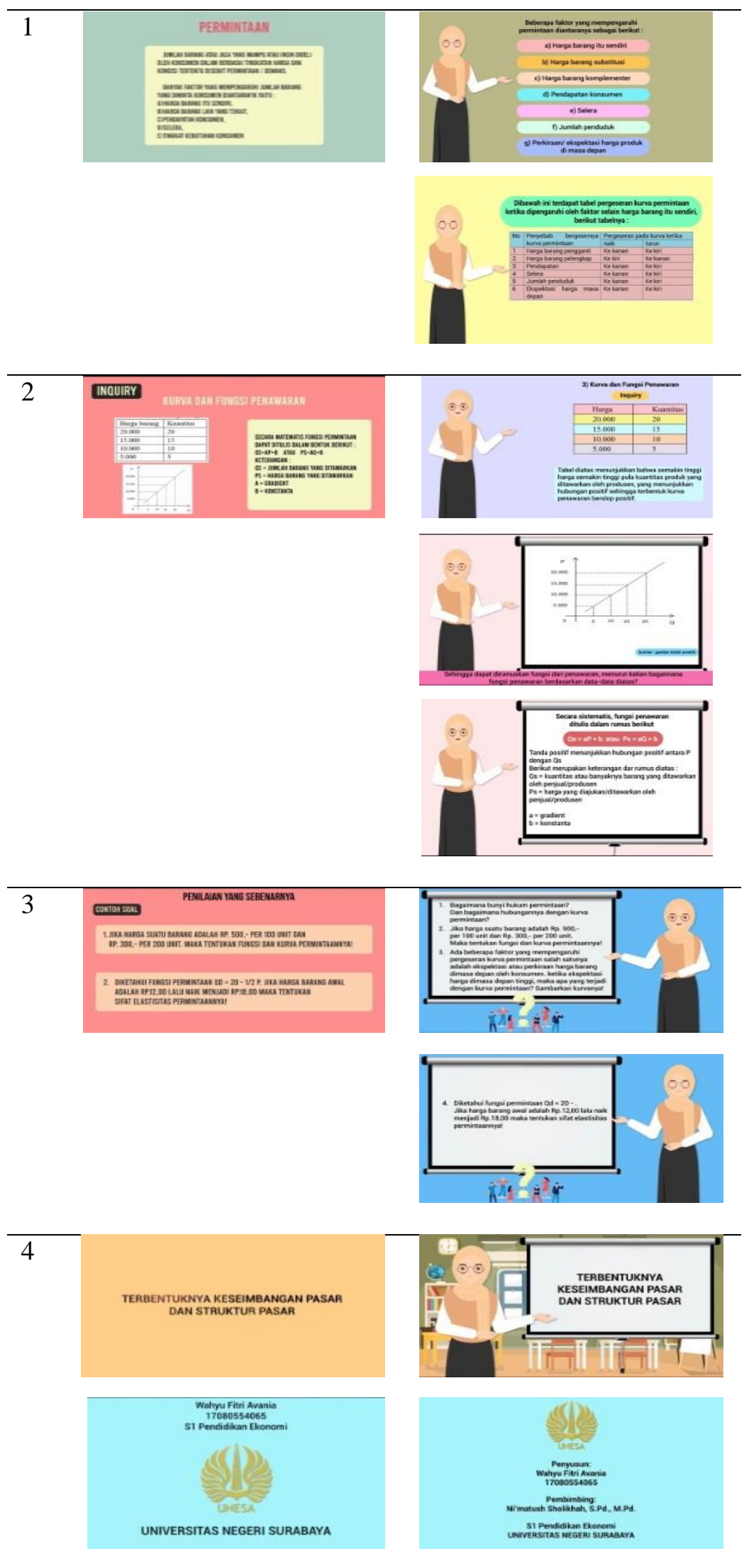

Edukatif : Jurnal Ilmu Pendidikan Vol 3 No 5 Tahun 2021 p-ISSN 2656-8063 e-ISSN 2656-8071 


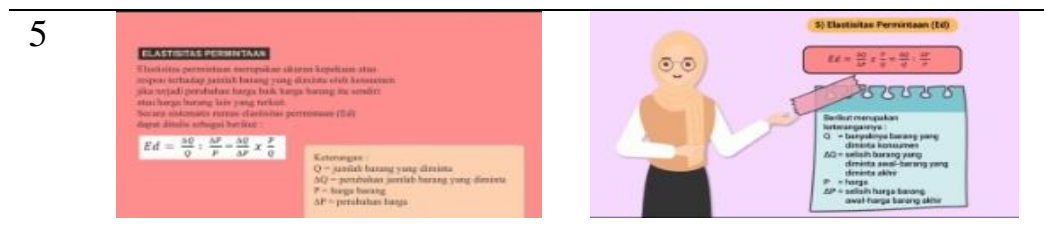

Sumber : data diolah peneliti

Setelah media direvisi oleh peneliti dengan berdasar pada hasil telaah oleh para ahli, maka akan dinilai kelayakannya ahli media serta ahli materi. Dalam tabel dibawah ini disajikan hasil rekap validasi oleh ahli :

Tabel 5. Hasil Validasi Media Pembelajaran Audio Visual dengan pendekatan CTL

\begin{tabular}{llcc}
\hline No & Aspek Penilaian & Skor rata-rata & Kategori \\
\hline Validasi Ahli Materi & & \\
\hline $1 \quad$ Kualitas Materi & 4,7 & Sangat layak \\
\hline 2 & $\begin{array}{l}\text { Kesesuaian dengan pendekatan } \\
\text { yang dipakai }\end{array}$ & 4,3 & Sangat layak \\
\hline $3 \quad$ Keberadaan contoh soal & 4,75 & Sangat layak \\
\hline $4 \quad$ Kebermanfaatan & 4,25 & Sangat layak \\
\hline \multicolumn{2}{l}{ Rata-rata } & $\mathbf{4 , 5}$ & Sangat layak \\
\hline Validasi Ahli Media & & \\
\hline $1 \quad$ Desain sampul & 3,86 & Layak \\
\hline 2 & Tata letak & 4,5 & Sangat layak \\
\hline 3 & Tipografi & 4,25 & Sangat layak \\
\hline $4 \quad$ Ilustrasi & 4,6 & Sangat layak \\
\hline Rata-rata & $\mathbf{4 , 3 0}$ & Sangat layak \\
\hline Rata-rata Hasil Validasi & $\mathbf{4 , 4}$ & Sangat layak \\
\hline S
\end{tabular}

Data hasil validasi diatas merupakan data deskriptif kuantitatif yang berbentuk angka yang akan dianalisis dalam bentuk kalimat/paragraf. Untuk validasi yang pertama yaitu validasi materi yang diinputkan dalam media yang meliputi empat aspek penilaian yaitu kualitas materi, kesesuaian dengan pendekatan yang dipakai, keberadaan contoh soal dan aspek kebermanfaatan. Tiap aspek penilaian memiliki rata-rata skor ,untuk kualitas materi yang ada pada media rata-rata skornya adalah 4,7; aspek kesesuaian dengan pendekatan yang dipakai rata-rata skornya adalah 4,3 ; selanjutnya untuk keberadaan contoh soal memiliki rata-rata skor 4,75 dan yang terakhir yaitu aspek kebermanfaatan memeroleh rata-rata skor yaitu 4,25. Jadi rata-rata skor dari seluruh penilaian validasi materi yaitu sebesar 4,5 dimana skor tersebut berada pada kategori sangat layak.

Untuk penilaian validasi ahli yang selanjutnya yaitu validasi media. Penilaian validasi media meliputi beberapa aspek yaitu aspek desain media bagian sampul, aspek tata letak, aspek tipografi dan yang terakhir adalah aspek ilustrasi. Tiap aspek penilaian memiliki skor rata- rata tiap aspeknya yaitu, untuk aspek desain sampul mendapatkan rata-rata skor 3,86; selanjutnya untuk aspek tata letak mendapatkan rata-rata skor sebanyak 4,5; yang ketiga yaitu aspek tipografi atau penulisan mendapat rata-rata skor 4,25 dan aspek terakhir yaitu aspek ilustrasi mendapatkan rata-rata skor 4,6. Jadi rata-rata skor dari semua aspek penilaian validasi media yaitu sebesar 4,30; dimana skor tersebut berada pada kategori sangat layak.

Perolehan skor dari dua penilaian validasi materi dan juga media adalah 4,4, dengan rincian validasi materi mendapat rata-rata skor 4,5 dan untuk validasi media mendapat rata-rata skor sebesar 4,30. Menurut Azwar (2007) mengenai konversi skor actual menjadi skala lima bahwa suatu media dikatakan layak ketika skor rata-rata yang diperolah adalah lebih dari 3,34. Dalam penelitian ini total skor rata-rata adalah 4,4 dimana skor tersebut berdasarkan konversi skor actual menjadi skala lima masuk dalam kategori sangat layak oleh (Azwar, 2007). 
Penelitian lain oleh Andrianti et al. (2016) dengan judul pengembangan media powtoon berbasis audio visual pada pembelajaran sejarah. Perbedaan penelitian ini dengan penelitian yang dilakukan peneliti adalah penelitian ini hanya mengembangkan sebuah media tanpa pengaplikasian untuk mengatasi motivasi belajar siswa yang rendah, namun penelitian yang dilakukan peneliti selain mengembangkan media juga mengaplikasikannya untuk dapat membantu meningkatkan motivasi belajar siswa. Pada penelitian ini juga mengukur kelayakan media audio visual powtoon. Dimana kelayakan diperoleh dari validasi materi, validasi desain dan validasi media dengan masing-masing skor sebesar 4,32; 4,00 dan 3,70 dengan skor akhir sebesar 4,1 yang berada pada kategori sangat layak. Media pembelajaran powtoon berbasis audio visual disimpulkan memiliki kriteria kelayakan yang sangat layak, sesuai dengan penelitian oleh peneliti mengenai pengembangan media pembelajaran audio visual dengan pendekatan Contextual Teaching Learning (CTL) dengan rata-rata skor akhir penilaian validasi 4,4 yang berada pada kategori sangat layak. Sehingga dapat ditarik kesimpulan bahwa media pembelajaran audio visual dengan pendekatan Contextual Teaching Learning $(C T L)$ sangat layak digunakan sebagai media pembelajaran baik dari segi materi maupun media.

\section{Kepraktisan media pembelajaran audio visual dengan pendekatan Contextual Teaching Learning (CTL)}

Guna mengetahui kepraktisan penggunaan media audio visual dengan pendekatan Contextual Teaching Learning (CTL) adalah menggunakan kuisioner respon yang diisi siswa X IPS 1 SMA N 14 Surabaya setelah penggunaan media dalam proses pembelajaran. Dibawah ini merupakan tabel hasil kuisioner respon siswa:

Tabel 6. Hasil Respon Siswa

\begin{tabular}{|c|c|c|c|}
\hline No & Aspek Penilaian & $\%$ rata-rata & Keterangan \\
\hline 1 & materi & 90,91 & sangat layak \\
\hline 2 & penyajian & 88,04 & sangat layak \\
\hline 3 & bahasa & 89,73 & sangat layak \\
\hline 4 & kebermanfaatan & 90,56 & sangat layak \\
\hline \multicolumn{2}{|c|}{ Rata-rata hasil respon siswa } & 89,81 & Sangat layak \\
\hline
\end{tabular}

Sumber : Data Diolah Peneliti (2021)

Data hasil respon siswa yang berupa angka ini nantinya akan dianalisis secara deskriptif kuantitatif menjadi sebuah kalimat atau paragraf. Hasil respon siswa ini dinyatakan dalam bentuk prosentase dan dihitung rata-rata tiap aspek penilaian. Untuk aspek yang pertama yaitu aspek materi memperoleh rata-rata prosentase sebesar 90,91\%; aspek penyajian media memperoleh rata-rata prosentase sebesar 88,04\%; aspek bahasa memperoleh rata-rata prosesntase sebesar $89,73 \%$ dan yang terakhir yaitu aspek kebermanfaatan memperoleh rata-rata presentase sebesar 90,56\%. Dari seluruh aspek penilaian respon yang diisi oleh siswa $\mathrm{X}$ IPS 1 SMA N 14 Surabaya memperoleh rata-rata prosentase sebesar 89,81\%. Menurut Riduwan (2012)mengenai kriteria interpretasi skor bahwa suatu media dikatakan layak apabila memperoleh prosentase rata-rata lebih dari sama dengan $61 \%$.

Dalam penelitian oleh Raisa et al. (2017) mengenai respon peserta didik terhadap media audio visual. Perbedaan penelitian ini dengan penelitian yang dilakukan peneliti adalah penelitian ini mengembangkan media dan mengukur respon sisa saja, namun penelitian yang dilakukan oleh peneliti selain mengembangkan dan mengukur respon siswa juga mengukur kelayakan media dan juga mengukur peningkatan motivasi belajar siswa. Penelitian Raisa et al. (2017) mengukur kepraktisan media pembelajaran yang dikembangkan melalui angket respon dengan dengan mendapat rata-rata prosentase $81 \%$ yang berada pada kategori sangat praktis atau sangat layak karena lebih dari sama dengan $81 \%$. Sesuai dengan penelitian ini dengan rata-rata prosentase kuisioner motivasi belajar siswa sebesar $89,81 \%$, dimana berada pada kategori sangat layak atau sangat praktis. Sehingga dapat disimpulkan bahwa penggunaan media pembelajaran audio visual dengan 
2548 Pengembangan Media Pembelajaran Audio Visual dengan Pendekatan Contextual Teaching Learning (CTL) untuk Meningkatkan Motivasi Belajar Siswa - Wahyu Fitri Avania, Ni'matush Sholikhah

DOI: https://doi.org/10.31004/edukatif.v3i5.885

pendekatan Contextual Teaching Learning (CTL) dalam pembelajaran ekonomi sangat praktis digunakan dalam pembelajaran ekonomi.

\section{Efektivitas media pembelajaran audio visual dengan pendekatan Contextual Teaching Learning $(C T L)$}

Guna mengetahui efektivitas media pembelajaran audio visual dengan pendekatan Contextual Teaching learning (CTL) adalah menggunakan kuisioner motivasi belajar yang diisi oleh siswa X IPS 1 SMA N 14 Surabaya sebelum dan sesudah penggunaan media. Untuk mengukur peningkatan motivasi belajar dengan menggunakan uji gain score berdasarkan jumlah skor motivasi belajar sebelum dan sesudah penggunaan media yang disajikan dalam tabel berikut :

Tabel 7. Total skor kuisioner motivasi belajar sebelum dan sesudah penggunaan media

\begin{tabular}{cc}
\hline $\begin{array}{c}\text { Total Skor Kuisioner Motivasi Belajar } \\
\text { Sebelum Peggunaan Media }\end{array}$ & $\begin{array}{c}\text { Total Skor Kuisioner Motivasi } \\
\text { Belajar Setelah Penggunaan Media }\end{array}$ \\
\hline 766 & 1421 \\
\hline
\end{tabular}

Sumber : data diolah peneliti

Berdasarkan data diatas dapat dilakukan perhitungan peningkatan motivasi belajar dengan uji gain score seperti dibawah ini:

$$
\begin{gathered}
\text { Gain score }=\frac{\text { skor kuisioner akhir }- \text { skor kuisioner awal }}{\text { skor maksimum - skor kuisioner awal }} \\
\text { Gain score }=\frac{1421-766}{(9 \times 5 \times 36)-766} \\
\text { Gain score }=\frac{655}{854}=0,77
\end{gathered}
$$

Setelah melalui perhitungan melalui uji gain score diperoleh nilai sebesar 0,77, dimana skor tersebut menurut Hake (1999) mengenai analisis kriteria peningkatan motivasi belajar dalam analisis gain score termasuk kedalam kategori yang tinggi. Menurut Hamalik (2009), bahwa ada beberapa upaya dalam membangkitkan motivasi siswa dalam belajar diantaranya yaitu dengan menggunakan media interaktif seperti video pembelajaran, menyampaikan tujuan pembelajaran, memberikan suasana baru seperti dengan bekerja kelompok.

Dalam media pembelajaran audio visual dengan pendekatan Contextual Teaching Learning (CTL) yang dikembangkan oleh peneliti terdapat tujuan pembelajaran yang akan dicapai sehingga siswa tau tujuan pembelajaran yang harus mereka capai setelah pembelajaran dilakukan. Karena media yang telah dibuat oleh peneliti menggunakan pendekatan Contextual Teaching Learning (CTL), didalamnya terdapat langkahlangkah ataupun tahapan pembelajaran yang membuat siswa merasa tidak bosan saat proses pembelajaran. Seperti kegiatan kerja kelompok atau diskusi bersama teman untuk mendiskusikan soal yang tertera dalam media, dengan adanya kegiatan diskusi akan menjadikan siswa aktif dan terjun secara langsung dalam proses belajar mengajar. Langkah-langkah pendekatan Contextual Teaching Learning (CTL) yang terdapat dalam media yakni pemodelan, dalam kegiatan ini materi yang disajikan dalam media dilengkapi dengan contoh gambar yang dikemas dalam bentuk animasi, hal ini akan membuat siswa terbentuk imajinasinya secara nyata akan objek yang ditampilkan. Dalam media terdapat contoh soal yang memuat semua indikator pembelajaran yang disajikan, dengan adanya contoh soal ini sebagai evaluasi bagi siswa mengenai materi yang telah dipelajari. Media juga dilengkapi dengan audio yang membuat media menjadi lebih menarik dan seakan terdapat interaksi secara langsung antara media dengan siswa karena dilengkapi dengan audio pendukung. Dalam pembelajaran ekonomi yang dilakukan oleh siswa X IPS 1 SMA N 14 Surabaya, hanya menggunakan LKPD berbayar dari sekolah yang tampilannya hanya hitam putih dan cenderung full text, dengan adanya media pembelajaran audio visual dengan menggunakan pendekatan Contextual Teaching Learning (CTL) ini 
menjadi suasana baru bagi siswa sehingga dapat membuat siswa menjadi meningkat minat serta motivasi belajar ekonominya.

Terdapat sejumlah penelitian yang serupa dengan penelitian peneliti diantaranya adalah penelitian yang membahas mengenai pengaruh media audio visual menggunakan pendekatan kontekstual terhadap hasil belajar dan motivasi belajar oleh Syupriyanti et al. (2019) bahwa penggunaan media interaktif berbasis audio visual menggunakan pendekatan CTL memiliki pengaruh yang positif pada hasil maupun motivasi belajar oleh siswa. Penelitian lain juga dikemukakan oleh Sarwinda et al. (2020) mengenai pengembangan media audio visual dengan menggunakan pendekatan kontekstual guna melatih kemampuan berpikir kritis dan meningkatkan motivasi belajar siswa. Penelitian tersebut memperoleh hasil bahwa proses belajar mengajar dengan mengaplikasikan pendekatan kontekstual yang diiringi media audio visual dapat membuat motivasi belajar siswa dan kemampuan berpikir kritis siswa menjadi meningkat.

Berdasarkan analisis menggunakan analisis gain score dan juga penjelasan mengenai kemampuan media audio visual dengan pendekatan Cotextual Teaching Learning (CTL) dalam meningkatkan motivasi belajar siswa diatas, maka dapat disimpulkan bahwa penggunaan media pembelajaran audio visual dengan pendekatan Contextual Teaching Learning (CTL) terbukti efektif meningkatkan motivasi belajar ekonomi siswa X IPS 1 SMA N 14 Surabaya. Namun penelitian pengembangan media audio visual dengan pendekatan Cotextual Teaching Learning (CTL) ini memiliki keterbatasan diantaranya yaitu untuk penyebaran media hanya melalui link google drive, Sehingga untuk penelitian selanjutnya diharapkan untuk mengembangkan media pembelajaran yang lebih praktis penyebaran dan penggunaannya bisa dikembangkan melalui aplikasi yang memuat video pembelajaran dan sebagainya. Penelitian ini hanya diaplikasikan di satu kelas yaitu X IPS 1, untuk penelitian selanjutnya agar bisa digunakan untuk semua kelas IPS untuk bisa meningkatkan motivasi belajar ekonominya. Selain itu materi yang terdapat di media juga hanya terbatas pada satu materi yaitu materi terbentuknya keseimbangan pasar dan struktur pasar, untuk penelitian selanjutnya agar bisa dikembangkan media pada materi lainnya agar bisa membantu siswa dalam belajar agar lebih menarik minat belajar dan motivasinya.

\section{KESIMPULAN}

Berdasarkan hasil penelitian pengembangan media audio visual dengan menggunakan pendekatan Contextual Teaching Learning (CTL), diperoleh kesimpulan yang menyatakan bahwa media pembelajaran audio visual dengan pendekatan Contextual Teaching Learning (CTL) sangat layak digunakan sebagai media pembelajaran, sangat praktis digunakan dan juga efektif dalam meningkatkan motivasi belajar siswa X IPS 1 SMA Negeri 14 Surabaya. Dengan rincian hasil skor validasi akhir sebesar 4,4 yang berada pada kategori sangat layak, rata-rata prosentase hasil respon siswaakhir sebesar 89,81 berada pada kategori sangat layak atau sangat praktis dan hasil nilai gain score sebesar 0,77 yang masuk dalam kategori peningkatan motivasi belajar yang tinggi.

\section{DAFTAR PUSTAKA}

Andrianti, Y., Susanti, L. R. R., \& Hudaidah. (2016). Pengembangan Media Powtoon Berbasis Audiovisual $\begin{array}{llll}\text { pada Pembelajaran Sejarah. Jurnal } & \text { Criksetra, }\end{array}$ https://ejournal.unsri.ac.id/index.php/criksetra/article/view/4802

Azwar, S. (2007). Tes Prestasi Fungsi dan Pengembangan Pengukuran Prestasi Belajar. Pustaka Belajar.

Bambang, L., Husain, S. N., \& Rede, A. (2015). Penerapan Pembelajaran Media Audio-Visual Untuk Meningkatkan Motivasi Dan Hasil Belajar Pada Mata Pelajaran Biologi Di Kelas VIII A SMP GKST Imanuel Palu. Jurnal Sains Dan Teknologi Tadulako, 4(1), 23-28. 
2550 Pengembangan Media Pembelajaran Audio Visual dengan Pendekatan Contextual Teaching Learning (CTL) untuk Meningkatkan Motivasi Belajar Siswa - Wahyu Fitri Avania, Ni'matush Sholikhah DOI: https://doi.org/10.31004/edukatif.v3i5.885

Ekowati, C. K., Darwis, M., Upa, H. M. D. P., \& Tahmir, S. (2015). The Application of Contextual Approach in Learning Mathematics to Improve Students Motivation At SMPN 1 Kupang. International Education Studies, 8(8), 81-86. https://doi.org/10.5539/ies.v8n8p81

Fauzyah, S., Hamdani, N. A., \& Margana, A. (2019). Pengaruh Penggunaan Media Pembelajaran Berbasis Audio Visual Terhadap Peningkatan Motivasi Dan Kompetensi Dasar Matematika Kelas V Di Sd Negeri 1 Cimaragas. Jurnal Tekniologi Pendidikan Dan Pembelajaran, 4(1), 799-815.

Hake, R. R. (1999). Analyzing Change/Gain Scores. Dept. of Physics, Indiana University. https://www1.physics.indiana.edu/ sdi/AnalyzingChange-Gain.pdf

Hamalik, O. (2009). Perencanaan Pengajaran Berdasarkan Pendekatan Sistem. PT Bumi Aksara.

Mulyatiningsih, E. (2012). Metode Penelitian Terapan Bidang Pendidikan. Alfabeta.

Novisya, D., \& Desnita. (2020). Analisis Pengembangan Video Pembelajaran Fisika Berbasis CTL pada Materi Fluida. Jurnal IPA \& Pembelajaran IPA, 4(2), 141-154. https://doi.org/10.24815/jipi.v4i2.16682

Raisa, S., Adlim, \& Safitri, R. (2017). Respon Peserta Didik Terhadap Pengembangan Media Audio-Visual. Jurnal Pendidikan Sains Indonesia, 5(2), 80-85. https://doi.org/10.24815/jpsi.v5i2.9821

Riduwan. (2012). Skala pengukuran Variabel-Variabel Penelitian. Alfabeta.

Rupawati, D., Noviani, L., \& Nugroho, J. A. (2017). Penerapan Media Pembelajaran Audio Visual Untuk Meningkatkan Hasil Belajar Ekonomi. Jurnal Pendidikan Ekonomi Manajemen Dan Keuangan, 01(01), 21-30. https://journal.unesa.ac.id/index.php/jpeka

Ryan, R. M., \& Deci, E. L. (2020). Intrinsic and extrinsic motivation from a self-determination theory perspective: Definitions, theory, practices, and future directions. Contemporary Educational Psychology, 61(xxxx), 101860. https://doi.org/10.1016/j.cedpsych.2020.101860

Sardiman, A. M. (2007). Interaksi dan Motivasi Belajar Mengajar. PT. Raja Grafindo Persada.

Sarwinda, K., Rohaeti, E., \& Fatharani, M. (2020). The development of audio-visual media with contextual teaching learning approach to improve learning motivation and critical thinking skills. Psychology, Evaluation, and Technology in Educational Research, 2(2), 98. https://doi.org/10.33292/petier.v2i2.12

Sugiyono. (2016). Metode Penelitian dan Pengembangan. Alfabeta.

Syarwah, R. A., Fauziddin, M., \& Hidayat, A. (2019). Peningkatan Motivasi Belajar Siswa Menggunakan Media Audio Visual pada Pembelajaran Bahasa Indonesia. Jurnal Pendidikan Tambusai, 3(5), 936-945.

Syupriyanti, L., Firman, \& Neviyarni. (2019). Pengaruh Media Audio Visual Interaktif Menggunakan Pendekatan CTL dalam Pembelajaran Tematik Terpadu terhadap Hasil Belajar dan Motivasi Siswa di Sekolah dasar. Jurnal Ilmu Pendidikan, 1(3), 237-243. https://edukatif.org/index.php/edukatif/index

Warti, E. (2018). Pengaruh Motivasi Belajar Siswa terhadap Hasil Belajar Matematika Siswa di SD Angkasa 10 Halim Perdana Kusuma Jakarta Timur. Mosharafa: Jurnal Pendidikan Matematika, 5(2), 177-185. https://doi.org/10.31980/mosharafa.v5i2.273

Werdhiana, I. K., Wahyono, U., \& Miftah. (2020). Implementasi Perangkat Pembelajaran Audio Visual IPA Berbasis Energi Surya untuk Meningkatkan Motivasi dan Minat Belajar Siswa SMP di Daerah Tertinggal. Jurnal Pendidikan Fisika Tadulako Online (JPFT), 8(1), 78-86.

Winarto, W., Syahid, A., \& Saguni, F. (2020). Effectiveness the Use of Audio Visual Media in Teaching Islamic Religious Education. International Journal of Contemporary Islamic Education, 2(1), 81-107. https://doi.org/10.24239/ijcied.vol2.iss 1.14 